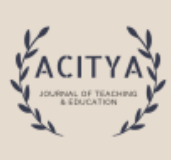

\title{
DEVELOPING READING SKILLS THROUGH GREEN CURRICULUM IMPLEMENTATION AS AN INSTRUCTIONAL MODEL
}

Sondang Pondan Perlindungan Leoanak ${ }^{1}$

${ }^{1}$ The State Polytechnic of Agriculture Kupang

Email: sonleo2002@yahoo.com

\begin{abstract}
This paper aims to investigate the implication of implementing green curriculum as an instructional model to increase English reading skills of the third semester students of Animal Feed Technology study program of Livestock department in the State Polytechnic of Agriculture Kupang (Politani) - NTT province. Additionally, students' perception on the application of green curriculum in increasing their reading skills also measured. For this purpose, the mixed method research design was applied as a mean to explore the information about students' knowledge and skills on English reading text before and after the application of green curriculum learning innovation. There were two groups of students: the experimental group (was facilitated using green curriculum teaching approach) and the control group (received conventional teaching strategy). Each groups consisted of 21 participants. The study reveals that, the students who received the application of green curriculum as learning innovation achieved better reading skills than those who did not receive any application of such teaching innovation. They also agreed that green curriculum application increased, supported and encouraged their competence in reading English text.
\end{abstract}

\section{Keywords: Green curriculum, implementation, instructional, reading}

This work is licensed under Creative Commons Attribution License 4.0 CC-BY International license

\section{INTRODUCTION}

\subsection{Introduction}

School environments (i.e. physical, natural and socio-cultural) carry important role for students' lives as it is a place of peers, teachers and curricular material to interact. Hence, the school environment should encourage, support and nurture students' growing capacities as learners through its green environment, curriculum and teaching-learning (Sharma \& Pandya, 2015). As a result, it is to be expected that the students will have connection with their surroundings and they will also be able to develop their knowledge, skills and attitudes towards the environment.

By this concept, educations have positive impacts upon ecological literacy and are achievable by development of a critical approach towards political, ideological and economic events (Kahn, 2010). More, Kahn (2010) called this approach towards education as 'eco-pedagogy or earth pedagogy'. Through eco-pedagogy, the notions of the protection of nature (natural ecology), the impact of the human societies upon nature (social ecology) as well as the influence over civilization and economic, social and cultural composition (integrated ecology) are the basis to promote respect for nature, human, culture and diversity (Okur, 2015). 
In fact, the subscription to all these notions should begin at schools and social groups (Antunes \& Gadotti, 2009). Fact also says that education has been recognized as one of the important tools for conserving the environment through the cultivation of knowledge, skills, values and positive attitudes towards the environment among the people (Kimaryo, 2011) Environmental education and its related concepts like environment and education for sustainable education are interrelated. To bring environmental issues in learning, both students and teachers must have a better understanding on environment.

The aim of environmental education is to ensure that learners have power to be the change for sustainability, needed by our world in which by engaging them in fun, action-orientated and socially responsible learning (Conneely, 2017). It is designed to encourage whole-school action on sustainable development issues. It also provides a framework for learning and establish link to sustainable development of education related to the everyday curricular work undertaken by schools - as well as enabling and encouraging closer links between schools and the communities around them (Conneely, 2017). There are some steps to be taken carefully in order to maximize the success of environmental education. One of the steps is to make a link of environmental education concept to the school curriculum. It is argued that the environmental education programme is most effective when it is integrated and linked to the school's curriculum and syllabus. More, it brings the integration among environmental issues and school action plans (curriculum) such as themes or topics studied (Conneely, 2017).

The curriculum in environmental education can be referred as the number of experiences that students undertake to help them develop environmental literacy, skills in solving problems, decision making, and active participation in taking action towards the environment as well as taking into consideration about the ecological, political, economic aspects (Palmer, 1998). This means that, environmental education curriculum entails the aspects of planning for instruction which shows what students need to know, how to achieve the intended goals, what teachers need to do to help students develop the required knowledge, and the context in which teaching and learning occurs (Kimaryo, 2011).

When environmental education implies in learning experience where the students have direct engagement with their surroundings, then, it represents the meaning of the concept of green curriculum. The main goal of green curriculum application is action. The action aims to improve the environment, prevent its degradation and sustain its well-being (Sharma \& Pandya, 2015). This sense of action will not only motivate students, but also create a sense of empowerment for students to make difference (Sharma \& Pandya, 2015). Furthermore, the concept of green curriculum is to fill the gap between what is taught and what is practiced by the students and to provide children with ample opportunities to connect with the real life. As a result, the process of teaching-learning will be enjoyable and meaningful for students. And finally, it would enable students to develop sensitivity and acquire relevant skills to address the real life environmental issues and problems (Sharma \& Pandya, 2015).

In addition to English teaching experiences, fact says that when students learn English language they need to deal with language support. This means that, they need more experiences and opportunities to hear or speak in English in the real world. To make it happen, the need of various teaching methods and teaching aids in the classroom is necessary needed (Leoanak \& 
Amalo, 2018a; Leoanak \& Amalo, 2018b; Leoanak \& Amalo, 2018c). Also, the demanding of using new modern technologies as teaching aids has been raised nowadays. However, the story would be different for the schools in the remote area such as Kupang regency, East Nusa Tenggara province - Indonesia. The fact says, most of the schools in this area cannot effort modern technology as their teaching aids in the classroom due to the lack of infrastructure, teaching media or human resources. So, it is assumed that, green curriculum would be the best solution to these phenomena.

In relation to the topic of this study, green curriculum can be used as an approach to select and apply English teaching materials based on students' personal knowledge about the environment. Teachers can use students' previous knowledge on environment as their source of information in compiling teaching materials. By doing so, it is hoped that the students will be easier to understand the teaching materials as they already have prior knowledge to the materials.

It is also argued that green curriculum approach is the solution to replace modern technology teaching approach such as the use of computers or LCD projectors (audio-video teaching aids) when explaining teaching materials. This can be done by taking the students outside the classroom, into the real world. For example, when talking about living things in water, teacher can take the students outside the classroom to observe it (e.g. visiting river, beach or ponds), rather than to watch it on television or computer. Another example is that, when explaining about how to plant a tree, the students can learn directly from the nature. They can visit their schoolyard to practice about how to plant a tree. The students can write down each of the steps to grow a tree as means of practicing their writing skills. This activity can also be continued by orally presenting their writing in front of the classroom where they can increase their speaking skill.

Thus, it can be said that by implementing green curriculum in English classroom, students can learn through real life, which is by practicing their learning materials in the real world. Having combining these opportunities with the activities that can be done outside classroom setting, provides the students a meaningful language learning experience which can increase their English skills. So, green curriculum can be used to provide a variety of English teaching experiences.

Many studies have been done regarding research on environmental education and green curriculum. Planning, examining and evaluation are necessary needed for successful environmental program implementation. Riordan \& Klein (2010) conducted a qualitative study to determine the impact of environmental learning in Expeditionary Learning Schools (ELS) on two middle school science teachers. They found that, students have better understanding and connection to the world when environmental learning technique applied.

Gedžūne (2012) studied the making sense of the ethics of relationships between humans and nonhuman nature. The study recounts an experience from an action research fragment in university setting where pre-service teachers are engaged in critical reflection on the ethical underpinnings of human relationships with nonhuman nature in the context of a study course "Environmental Pedagogy". The study suggests that ethical dilemma can be used as a means to promote pre-service teachers' critical reflection on human relationships with nonhuman nature. This study also implies that on a personal level the students' make sense of their own relationships with nonhuman nature through frames of reference that acknowledge their inclusion in the Earth's 
community of life where the interest of the whole and all its parts is interrelated and interdependent.

Shanely (2006) conducted a qualitative study with four sixth-graders involved in an outdoor education program where students used cameras to explore plants and animals in nature. Shanely (2006) found that the sixth graders in the outdoor education program perceived their outdoor experience as positive and agreed to implement a plan to care for the outdoors when they returned home.

\subsection{Research aims}

Based on the introduction stated above, this research aims to find out the implication of implementing green curriculum as an instructional model to increase students' English competence on reading skills. However, this study also aims to bring solution to English learners, especially to the students of the State Polytechnic of Agriculture Kupang (SPAK) in East Nusa Tenggara province who have difficulties in comprehending English reading text perfectly. Additionally, this study also intends to see students' perception on the application of green curriculum in increasing their reading skills. Hopefully, the result of this study may increase students' awareness in using green media to improve their reading skills and competencies.

\section{METHOD}

\subsection{Research design}

In the present study, the implication of green curriculum in improving English reading skills of the third semester students of Animal Feed Technology study program of Livestock department in SPAK was evaluated through mixed method research design. The mixed method research design provided an opportunity to combine quantitative and descriptive research methodologies to evaluate the data for this study (Creswell \& Clark, 2011). These methods was applied as a mean to explore the information about students' knowledge and skills in English reading text before and after the application of green curriculum as teaching innovation and their perception on the application of green curriculum in developing their reading skills.

There were two groups of students; the experimental group and the control group. Each groups consisted of 21 participants. The experimental group was facilitated using green curriculum approach, while the control group received conventional teaching strategy over the same period of time. The application of green curriculum approach in reading class to the experimental group was done within 4 months. The length of the changes in students' English performance (reading comprehension skills) of both groups after the application of green curriculum approach were elaborated in details based on this experimental research result.

Quantitative research design was conducted to collect data from pre-test and post-test of both groups. After collecting the required quantitative data, a descriptive method was applied to elaborate students' performances on reading text of pre-test and post-test of experimental and control groups as well as their perception on the application of green curriculum.

This study also applied a questionnaire to find out students' perception on the application of green curriculum in developing their reading skills. The questionnaire was a type of close-ended questions and it consisted of 10 statements and the answer was ranging from strongly agree (5), 
agree (4), uncertain (3), disagree (2) and strongly disagree (1). The questions in the questionnaire were composed based on Conneely's (2017) and Kimaryo's (2011) concept green education. This questionnaire was administrated to experimental group only.

\subsection{Population and sample}

The population of control and experimental group of this study consisted of the second year students SPAK. The sample taken were the students from Animal Feed Technology study program of Livestock department of SPAK. The participants from control group were 21 students and the total participants in experimental group were 21 students. So, the total number of the participants of both group were 42 students. These participants consisted of 20 males and 22 females, and their age range was 18 to 21 years old.

\subsection{Research instrument}

A pre-test and a post-test were applied as research instrument in the present study. The same pre-test and post-test were delivered to control and experimental group. The test consisted of two reading text and each text consisted of 10 multiple-choice questions with five options. So, the total number of the question was 20 number. The topic of the first text was about "How to make your own poultry feed" (Leoanak, 2018). The second text was about "The science of animal breeding" (Leoanak, 2019). The chosen reading texts were based under consideration of students' language proficiency level and content familiarity.

\subsection{Method of data analysis}

To find out the effectiveness of developing reading skill through green curriculum as learning innovation, students' mean and standard deviation score of pre-test and post-test of control and experimental group were calculated. Students' mean and standard deviation score were analyzed using IBM SPSS 25 program.

\subsection{Research hypotheses}

The hypotheses applied in the present study were: the null hypothesis (Ho) meant there was no significant development on students' reading skills through green curriculum as learning innovation. The alternative hypothesis (Ha) meant there was significant development on students' reading skills through green curriculum as learning innovation.

\section{FINDINGS AND DISCUSSION}

\subsection{Findings}

To find out the implication of implementing green curriculum as learning innovation to develop students' reading skills, means and standard deviations of the students' reading comprehension scores for experimental and control group were calculated using IBM SPSS 25 program. The result of the pre-test is shown in the Table 1. 
Table 1. Mean and standard deviation of pre-test.

\begin{tabular}{|c|c|c|c|c|c|c|}
\hline Group & $\mathbf{N}$ & Mean & $\begin{array}{l}\text { Standard } \\
\text { Deviation }\end{array}$ & $\begin{array}{c}\text { Standard } \\
\text { Error }\end{array}$ & $\begin{array}{c}\text { Minimum } \\
\text { Score }\end{array}$ & $\begin{array}{c}\text { Maximum } \\
\text { Score }\end{array}$ \\
\hline Experimental & 21 & 57.1429 & 5.82482 & 1.27108 & 50 & 70 \\
\hline Control & 21 & 56.9048 & 3.70006 & .80742 & 50 & 60 \\
\hline
\end{tabular}

The Table 1 above shows the mean and standard deviation score of students' pre-test result. From the Table 1, it can be seen that the mean score of experimental group is 57.1429 while the mean score of control group is 56.9048. The mean difference between experimental and control group was only slightly different that is 0.24 . Therefore, it can be concluded that the score of pretest for both groups does not show significance difference before the application of the development on students' reading skills through green curriculum as learning innovation took place. The Table 1 also reveals that both group share the same minimum score that is 50 . However, experimental and control group share different maximum score which is 70 for experimental group and 60 for control group.

The Table 2 shows the result of the post-test of the experimental and control group.

Table 2. Mean and standard deviation of post-test

\begin{tabular}{|l|c|c|l|l|l|l|}
\hline \multicolumn{1}{|c|}{ Group } & $\mathbf{N}$ & Mean & $\begin{array}{c}\text { Standard } \\
\text { Deviation }\end{array}$ & $\begin{array}{c}\text { Standard } \\
\text { Error }\end{array}$ & $\begin{array}{c}\text { Minimum } \\
\text { Score }\end{array}$ & $\begin{array}{c}\text { Maximum } \\
\text { Score }\end{array}$ \\
\hline Experimental & 21 & 73.5714 & 5.03559 & 1.09886 & 70 & 85 \\
\hline Control & 21 & 62.1429 & 4.350 .70 & .94940 & 55 & 70 \\
\hline \multicolumn{2}{|l}{ Mean differences between experimental and control group $=11.43$} & & \\
\hline
\end{tabular}

The Table 2 above shows the mean and standard deviation score of students' post-test result. It can be seen from the Table that the mean score of experimental group is 75.5714 while the mean score of control group is 62.1429. The mean difference between experimental and control group was only slightly different that is 11.43 . Therefore, this means that the average score of post-test of experimental group is considerable higher than the one in control group. In addition, it clearly seen from the Table 2 that the minimum score gained by experimental group participant is 70 , while the control group is 55. While the maximum score achieved by experimental group participant is 85 and 70 for control group.

The Table 3 below shows the result of the t-test for the groups.

Table 3. T-test result of the post-test

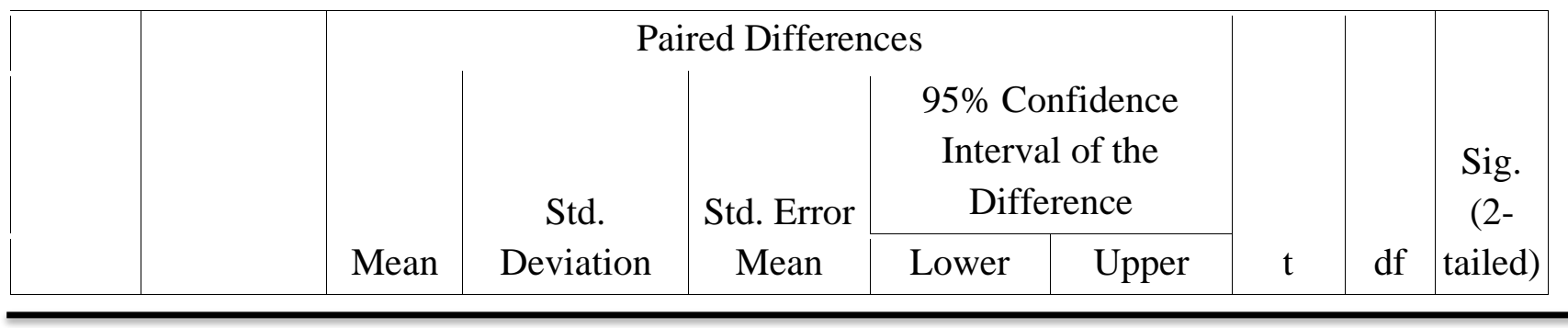


Table 3. T-test result of the post-test

\begin{tabular}{|c|c|c|c|c|c|c|c|c|c|}
\hline & & \multicolumn{5}{|c|}{ Paired Differences } & \multirow[b]{3}{*}{$\mathrm{t}$} & \multirow[b]{3}{*}{$\mathrm{df}$} & \multirow{3}{*}{$\begin{array}{l}\text { Sig. } \\
(2- \\
\text { tailed })\end{array}$} \\
\hline & & \multirow[b]{2}{*}{ Mean } & \multirow{2}{*}{$\begin{array}{c}\text { Std. } \\
\text { Deviation }\end{array}$} & \multirow{2}{*}{$\begin{array}{l}\text { Std. Error } \\
\text { Mean }\end{array}$} & \multicolumn{2}{|c|}{$\begin{array}{l}95 \% \text { Confidence } \\
\text { Interval of the } \\
\text { Difference }\end{array}$} & & & \\
\hline & & & & & Lower & Upper & & & \\
\hline Pair 1 & $\begin{array}{l}\text { Experimen } \\
\text { tal - } \\
\text { Control }\end{array}$ & 1.14286 & 6.54654 & 1.42857 & 8.44862 & 14.40852 & 8.000 & 20 & .001 \\
\hline
\end{tabular}

The result of the t-test of the post-test is shown in the Table 3 above. Santoso (2016) points out that, if the value of Sig. (2-tailed) $<0,05$, then the null hypothesis (Ho) is rejected and the alternative hypothesis (Ha) is accepted. However, if the value of Sig. (2-tailed) > 0,05, then Ho is accepted and $\mathrm{Ha}$ is rejected. The Table 3 above shows that the value of Sig. (2-tailed) of the post test is 0,001 which is smaller than $0,05(0,001<0,05)$.

The Table 4 below shows the result of the questionnaire addressed to the students of experimental group.

Table 4. Experimental students' perception on the application of green curriculum

\begin{tabular}{|c|c|c|c|c|c|c|}
\hline No & Questions & $\begin{array}{c}1 \\
\text { (strongly } \\
\text { disagree) }\end{array}$ & $\begin{array}{c}2 \\
\text { (disagree) }\end{array}$ & $\begin{array}{c}3 \\
\text { (uncertain) }\end{array}$ & $\begin{array}{c}4 \\
\text { (agree) }\end{array}$ & $\begin{array}{c}5 \\
\text { (strongly } \\
\text { agree) }\end{array}$ \\
\hline 1. & $\begin{array}{l}\text { Help me to engage in the } \\
\text { learning/teaching process. }\end{array}$ & 0 & 0 & 0 & 14.3 & 85.7 \\
\hline 2. & $\begin{array}{lcr}\text { Empower me to } & \text { take } \\
\text { informed decisions } & \text { and } \\
\text { actions on real } & \text { life } \\
\text { sustainability issues. } & \end{array}$ & 0 & 0 & 0 & 9.5 & 90.5 \\
\hline 3. & $\begin{array}{l}\text { Encourage me to work } \\
\text { together actively. }\end{array}$ & 0 & 0 & 0 & 38.1 & 61.9 \\
\hline 4. & $\begin{array}{l}\text { Encourage me to involve in } \\
\text { collaborative solutions. }\end{array}$ & 0 & 0 & 0 & 33.3 & 66.7 \\
\hline 5. & $\begin{array}{l}\text { Support me to examine my } \\
\text { assumptions, in order to } \\
\text { develop critical thinking, } \\
\text { and to be open to change. }\end{array}$ & 0 & 0 & 0 & 47.6 & 52.4 \\
\hline 6. & $\begin{array}{l}\text { Support me to examine my } \\
\text { knowledge, in order to } \\
\text { develop critical thinking, } \\
\text { and to be open to change. }\end{array}$ & 0 & 0 & 0 & 42.9 & 57.1 \\
\hline 7. & Support me to examine my & 0 & 0 & 0 & 28.6 & 71.4 \\
\hline
\end{tabular}




\begin{tabular}{|c|c|c|c|c|c|c|}
\hline & $\begin{array}{l}\text { experiences, in order to } \\
\text { develop critical thinking, } \\
\text { and to be open to change. }\end{array}$ & & & & & \\
\hline 8. & $\begin{array}{l}\text { Encourage me to share my } \\
\text { inspirational stories of my } \\
\text { achievements, to learn from } \\
\text { them, and to support each } \\
\text { other. }\end{array}$ & 0 & 0 & 19.0 & 28.6 & 52.4 \\
\hline 9. & $\begin{array}{l}\text { Encourage me to share my } \\
\text { inspirational stories of my } \\
\text { failures, to learn from them, } \\
\text { and to support each other. }\end{array}$ & 0 & 0 & 14.3 & 33.3 & 52.4 \\
\hline 10. & $\begin{array}{l}\text { Encourage me to share my } \\
\text { inspirational stories of my } \\
\text { values, to learn from them, } \\
\text { and to support each other. }\end{array}$ & 0 & 0 & 0 & 57.1 & 47.6 \\
\hline & Average & $\mathbf{0 , 0}$ & $\mathbf{0 , 0}$ & 3,3 & 33,3 & 63,8 \\
\hline
\end{tabular}

The Table 4 above shows that there are 21 students of experimental who took part in responding to the given questionnaire. It is clearly seen that, most of the students agree that the application of green curriculum increased their reading skills. None of the students disagreed that the application of green curriculum did not increase their reading skills, so the percentage is $0 \%$. However, about $3,3 \%$ of the students was not certain whether the application of green curriculum increased their reading skills. And about $97 \%$ of the students agree that their reading skills were increased after implementing green curriculum.

\subsection{Discussion}

The research findings reveal that before the implementation of green curriculum as teaching innovation to the second year of SPAK students, there was no significance difference of students' reading skills among all participants. However, after the application of green curriculum as teaching innovation in reading classroom, a significant difference of reading skills was found between experimental group and control group. It was found that the mean difference between these two groups was 11.43 which considered higher than the control group.

The results of the t-test shows that the value of Sig. (2-tailed) of the post test is 0,001 . This value is smaller than 0,05 . So, it can be concluded that, the null hypothesis (Ho) is rejected and the alternative hypothesis (Ha) is accepted. The result of the study reveals that the null hypothesis (Ho) is rejected because there is a significant development on students' reading skills through the application of green curriculum as learning innovation. Thus, the alternative hypothesis (Ha) is accepted as students' performance on reading comprehension is improved after the application of green curriculum as learning innovation compared to conventional teaching method. 
The experimental students' responses to the given questionnaire shows that green curriculum brings positive impact when it is applied in English classroom, as it increases their reading skills. Most of the students agreed that the application of green curriculum influenced their behavior, motivation and academic achievement in relation to the engagement in the teaching and learning process (Kahn, 2010), empower them to take informed decisions and actions on certain issues (Okur, 2015). The students also agreed that by green curriculum application, they can work together actively, involve in collaborative solution, develop their critical thinking, and to be open to change by examining their assumptions, knowledge, and experiences. Similar to the study conducted by Riordan \& Klein (2010), this study found that green curriculum supported students in examining their knowledge and experiences, in order to develop their critical thinking, and to be open to change.

Similar to other curriculums model (Bobkina \& Domingguez, 2015; Bertram \& Judith, 1996), green curriculum serves as a detail plan for teachers in which it specifies students' activities, assignment and assessment in the classroom. For this purpose, standards need to be set up to support teachers' decision-making classroom performances. In relation to the topic of this study, there are three language standards for learning a language: to communicate interpersonally, to interpret, and to present information and ideas (Bobkina \& Domingguez, 2015). By these notions, it was found that the application of green curriculum in developing students' reading skills was to encourage the students to share their inspirational stories of their achievements, failures, and values, to learn from them, and to support each other.

The finding of the study provided empirical answer to the previously stated study question that, the application of green curriculum as teaching innovation helps to increase students' reading skills and stimulate their passion in English classroom, especially during reading classes. The present study also supports the previous studies (Kahn, 2010; Okur, 2015; Riordan \& Klein, 2010 ; Shanely, 2006) about the achievement of better understanding when environmental education and green curriculum learning innovation applied.

\section{CONCLUSIONS}

\subsection{Conclusions}

The implication of this study is that, students who received the application of green curriculum as learning innovation achieved better reading comprehension than those who did not receive any application of green curriculum as learning innovation. Most of the students agreed that the application of green curriculum as teaching model increased their competence in reading English text. So, it can be concluded that the application of green curriculum as learning innovation is powerful in helping students increase their reading comprehension.

\subsection{Suggestions}

This study suggests that, green curriculum can be applied as a learning innovation to increase students' reading competence. Teachers and educators are suggested to apply green curriculum as an instructional model in their reading classroom as it enhances students' reading skills. It is also suggested that, the future study can focus on students with different background 
(business, management, engineering, fishery, etc.) as well as different English skills (listening, speaking, writing or grammar).

\section{REFERENCES}

Antunes, A. \& Gadotti, M. (2009). Eco-pedagogy as the appropriate pedagogy to the earth charter process. The Earth Charter in Action, Part IV: Democracy, Nonviolence and Peace. Retrieved August 2017, http://www.earthcharterinaction.org/invent/images/uploads/ENGAntunes.pdf

Bertram, C.B. \& Judith, D. (1996). An Inquiry Model for Literacy Across the Curriculum. Journal of Curriculum Studies, 28 (3). pp. 281-300.

Bobkina, J. \& Domingguez, E. (2015). English Language and Literature: Towards a Model for Implementation of the English/Spanish Bilingual Curriculum in Spain. English language teaching. Vol 8(2). DOI: http://dx.doi.org/10.5539/elt.v8n2p1

Conneely. B. (2017). Eco-schools handbook: Engaging the youth of today to protect the climate of tomorrow. Foundation for Environmental Education. Denmark.

Creswell, J. W. \& Clark, V. L. P. (2011). Designing and conducting mixed methods research (2nd ed.). Thousand Oaks, CA: Sage Publication, Inc.

Gedžūne, I. (2012). Making Sense of the Ethics of Relationships between Humans and Nonhuman Nature: An Action Research Experience. New Technologies, Education for Sustainable Development and Critical Pedagogy. Vassilios Makrakis \& Nelly Kostoulas-Makrakis (Eds.). Information and Communication Technology, Enabled Education for Sustainable Development (ICTeESD). University of Crete. pp 252-266.

Kahn, R., (2010). Critical pedagogy, ecoliteracy, \& planetary crisis. New York: Peter Lang Publishing, Inc.

Kimaryo, L.A. (2011). Integrating Environmental Education in Primary School Education in Tanzania: Teachers' Perceptions and Teaching Practices. Åbo Akademi University Press.

Leoanak, S. P. P., \& Amalo, B. K. (2018a). Teacher's behaviour towards students' motivation practice. In SHS Web of Conferences (Vol. 42, p. 00078). EDP Sciences. DOI: https://doi.org/10.1051/shsconf/20184200078.

Leoanak, S. P. P., \& Amalo, B. K. (2018b). Utilizing waste materials as a medium of English instruction. ELT Echo: The journal of English language teaching in foreign language context. Vol. 3(1). pp. 22-34. DOI: http://dx.doi.org/10.24235/eltecho.v3i1.2590

Leoanak, S. P. P., \& Amalo, B. K. (2018c). Teachers' beliefs and perceptions of code switching in English as foreign language classroom. In SHS Web of Conferences (Vol. 42, p. 00034). EDP Sciences. DOI: https://doi.org/10.1051/shsconf/20184200034.

Leoanak, S.P.P. (2018). English in use for Agricultural Students. Deepublish Publication. Yogyakarta. 
Leoanak, S.P.P. (2019). English in use for Animal Husbandry Students. Deepublish Publication. Yogyakarta.

Okur, B.E. (2015). The Effect of Ecopodagogy-Based Environmental Education on Environmental Attitude of In-service Teachers. International Electronic Journal of Environmental Education. LIC (Livestock Improvement Corporation), Hamilton, New Zealand. Vol. 5(2). pp 86-110.

Palmer, J. A. (1998). Environmental Education in the 21st Century: Theory, Practice, Progress and Promise. Routledge, London.

Riordan, M., \& Klein, E. J. (2010). Environmental education in action: How expeditionary learning schools support teachers in tackling issues of sustainability. Teacher Education Quarterly. Vol. 37(4). pp 120-137.

Santoso, S. (2016). Panduan Lengkap SPSS Versi 23. Elex Media Komputindo.

Shanely, S. D. (2006). Towards an understanding of an outdoor education program: listening to participants' stories. (Doctoral dissertation). Available from ProQuest Dissertations and Theses database.

Sharma, K \& Pandya, M. (2015). Towards a Green School on Education for Sustainable Development for Elementary Schools. Resource Book. New Delhi. 